\title{
PENERAPAN MODEL PEMBELAJARAN MIND MAPPING TERHADAP KEMAMPUAN KONEKSI DAN KECEMASAN MATEMATIK SISWA SMP
}

\author{
Risma Puspitasari ${ }^{1}$, Yanti Mulyanti ${ }^{2}$, Ana Setiani ${ }^{3}$ \\ 1,2,3 Universitas Muhammadiyah Sukabumi \\ ${ }^{1}$ risma.puspitasari.rhiz@gmail.com \\ 2 yanti_khairan@yahoo.co.id \\ 3 ana.setiani.math@gmail.com
}

\begin{abstract}
ABSTRAK
Penelitian ini bertujuan untuk mengetahui apakah siswa yang belajar menggunakan model pembelajaran Mind Mapping lebih baik daripada siswa yang belajar dengan menggunakan model pembelajaran langsung, dan diduga kecemasan matematika siswa dengan model pembelajaran Mind Mapping lebih rendah daripada siswa dengan model pembelajaran langsung. Populasi dalam penelitian ini adalah siswa kelas VII SMPIT Adzkia Sukabumi dengan sampelnya diambil dua kelas secara acak, satu kelas sebagai kelas eksperimen yaitu kelas VII-F yang diberikan perlakuan dengan model pembelajaran Mind Mapping dan kelas yang satunya yaitu kelas VII-E sebagai kelas kontrol yang diberikan perlakuan dengan menggunakan pembelajaran langsung. Instrumen yang digunakan dalam penelitian ini adalah tes kemampuan koneksi matematis serta angket kecemasan matematika dengan skala Likert. Analisis data menggunakan metode True Experimental Design dengan desain pretest-postest control group design. Berdasarkan analisis data menggunakan uji-t kemampuan koneksi matematis diperoleh nilai $\mathrm{t}_{\text {hitung }}=-6,000$ sedangkan nilai $\mathrm{t}_{\text {tabel }}=-2,326$. Sehingga $\mathrm{H}_{0}$ ditolak atau $\mathrm{H}_{1}$ diterima karena $\mathrm{t}_{\text {hitung }}<\mathrm{t}_{\text {tabel. }}$. Hal ini menunjukkan bahwa kemampuan koneksi matematis siswa kelas eksperimen dengan model pembelajaran Mind Mapping lebih baik daripada kelas kontrol dengan model pembelajaran langsung. Sehingga diperoleh kesimpulan bahwa (1) Kemampuan koneksi matematis siswa dengan model pembelajaran Mind Mapping lebih baik daripada siswa dengan model pembelajaran langsung. (2) Kecemasan matematika siswa dengan model pembelajaran Mind Mapping lebih rendah daripada siswa dengan model pembelajaran langsung.
\end{abstract}

Kata Kunci: kemampuan koneksi matematis, kecemasan matematika, Mind Mapping.

\begin{abstract}
This study aims to determine whether students who learn with mind mapping learning models are lower than students who learn with direct learning models. It is suspected that mathematics anxiety of students with Mind Mapping learning models is lower than students with direct learning models. Population in this study are seventh-grade students of Adzkia Middle School Sukabumi with a sample from two class that taken randomly. One class as an experiment class (VII-F) treated with Mind Mapping learning model and the other class (VII-E) as the control class treated using direct learning. The instrument used in this study was a test of mathematical connection ability and mathematics anxiety questionnaire with a Likert scale. The data analysis used True Experimental Design methods with pretest-posttest control group design. Based on data analysis using t-test mathematical connection ability obtained the value of thing tvalue $=-6,000$ while the value of $t_{\text {table }}=-2,326$. So that $H_{0}$ rejected or $H_{1}$ accepted because of $t_{\text {value }}<t_{\text {table. }}$. It shows that the mathematical connection ability of the experimental class students with the Mind Mapping learning model is better than the control class with the direct learning model. It can be concluded that (1) the mathematical connection ability of students with Mind Mapping learning models is
\end{abstract}


better than students with direct learning models. (2) mathematical anxiety of students with mind mapping learning models is lower than students with direct learning models.

Keywords: students mathematical connection ability, mathematics anxiety, Mind Mapping.

\section{PENDAHULUAN}

Pesatnya perkembangan zaman dengan adanya era globalisasi dan informasi menuntut setiap manusia untuk siap menghadapi persaingan dengan manusia lain. Untuk dapat bersaing dan dapat bertahan maka harus memiliki kualitas sumber daya manusia yang baik, handal, memiliki kemampuan berpikir kritis, sistematis, logis, dan mampu mengkomunikasikan ide-ide kreatifnya dengan baik. Untuk meningkatkan sumber daya manusia yang berkualitas, sektor pendidikan memegang peranan yang sangat penting.

Matematika adalah salah satu mata pelajaran yang sangat penting yang diajarkan di setiap jenjang pendidikan, mulai dari Sekolah Dasar bahkan Tingkat Kanak-kanak. Sebagaimana dikemukakan oleh Novianti (2016:1) bahwa "Dalam setiap kurikulum pendidikan nasional, mata pelajaran matematika selalu diajarkan di setiap jenjang pendidikan dan di setiap tingkatan kelas". Permendiknas No. 22 tahun 2006 menyatakan bahwa "pembelajaran matematika perlu diberikan pada semua peserta didik dimulai dari Sekolah Dasar. Dengan tujuan siswa dapat memiliki kemampuan berpikir logis, analitis, sistematis, kritis, kreatif, dan mampu bekerja sama secara efektif". Hal tersebut menunjukkan betapa penting pelajaran matematika sehingga harus dipelajari sejak usia dini.

Dalam National Council of Teachers of Mathematics (Riyanto, 2016:2) disebutkan bahwa "Standar kemampuan matematis yang harus dimiliki oleh siswa yaitu: pemecahan masalah (problem solving), komunikasi (communication), penalaran (reasoning), koneksi (connection), representasi (representation)". Salah satu komponen dari kelima standar di atas adalah kemampuan koneksi matematis. Kemampuan koneksi matematis adalah kemampuan menerapkan konsep-konsep matematis yang telah dipelajari terhadap masalahmasalah yang berkaitan baik dalam konteks bidang matematika maupun dalam disiplin ilmu lainnya.

Menurut Mariana (dalam Sari, 2014:3) dikemukakan bahwa "Kemampuan koneksi matematis belum maksimal dikembangkan pada sekolah-sekolah di Indonesia". "Pembelajaran matematika sekolah cenderung hanya bertujuan seperti meningkatkan aspek kognitif dan psikomotor saja tanpa memperhatikan mutu dan aspek matematika yang lain. Pembelajaran seperti itu hanya memacu kerja otak kiri, sedangakan otak kanan yang 
berhubungan dengan warna, gambar, imajinasi dan kreatifitas belum digunakan secara optimal, akibatnya proses berfikir kreatif siswa menjadi terhambat"(Sari, 2014:3). Ruspiani (Gantinah, 2014:410) mengungkapkan bahwa rata-rata kemampuan mengoneksi matematis siswa tingkat menengah masih rendah, nilai rata-ratanya 60 pada skor total 100 .

Dalam penelitian yang dilakukan oleh Nelly Yuliana (2013) bahwa "Mata pelajaran matematika merupakan salah satu mata pelajaran yang masih dianggap sulit oleh sebagian besar siswa-siswi. Hal ini menjadikan matematika sebagai momok yang menakutkan bagi sebagian siswa. Saat kegiatan belajar mengajar matematika, masih banyak siswa yang mengeluh, merasa cemas, was-was (khawatir), bahkan tak yakin ketika siswa hendak memulai pelajaran. Wajah siswa pun menunjukkan roman tak berdaya dan ketakutan, padahal belum melakukan kegiatan apa-apa. Ketakutan atau rasa takut akan matematika dapat diartikan sebagai kecemasan matematika”.

Pada dasarnya hasil belajar matematika siswa dipengaruhi oleh beberapa faktor, diantaranya sikap siswa pada matematika, konsep diri dan kecemasan siswa dalam belajar. Hasil penelitian menunjukan bahwa kemampuan koneksi matematis siswa masih dikatakan rendah dan kecemasan matematika siswa masih tinggi. Permasalahan-permasalahan tersebut didukung dengan data dari hasil ulangan harian matematika selama tiga tahun terakhir yang dalam ulangan tersebut terdapat indikator-indikator tentang kemampuan koneksi matematis, seperti pada Tabel 1.

Tabel 1. Hasil Nilai Ulangan Harian Pelajaran Matematika 3 Tahun Terakhir

\begin{tabular}{cccc}
\hline & $2016 / 2017$ & $2017 / 2018$ & $2018 / 2019$ \\
\hline Nilai rata-rata & 55,04 & 55,00 & 48,20 \\
Nilai Tertinggi & 80,00 & 80,00 & 75,00 \\
Nilai Terendah & 30,00 & 30,00 & 25,00 \\
Standar Deviasi & 14,34 & 14,38 & 13,99 \\
\hline & (Sumber: data ulangan harian SMPIT Adzkia Sukabumi)
\end{tabular}

Dari data diatas diperoleh bahwa terdapat masalah terhadap rendahnya kemampuan koneksi matematis dan masih tingginya kecemasan matematika siswa SMP. Maka dalam penelitian ini peneliti ingin memberikan tindakan-tindakan dalam upaya untuk memberikan kualitas pembelajaran untuk memperbaiki kinerja sebagai guru sehingga kemampuan koneksi matematis siswa dan kecemasan matematika dapat diatasi.

Hal tersebut disebabkan pembelajaran matematika yang diterapkan di kelas masih sering menggunakan pembelajaran ceramah (teacher centered) sebagai sumber pengetahuan. Sehingga proses pembelajaran hanya satu arah. Siswa hanya mencontoh dan mencatat bagaimana cara menyelesaikan soal yang telah dikerjakan oleh gurunya. Akibatnya gurulah yang banyak berperan dalam proses pembelajaran. Hal itu pun dapat 
memperparah kecemasan matematika siswa. Kecemasan merupakan unsur kejiwaan yang menggambarkan suatu keadaan perasaan, keadaan emosional, gelisah, ketidak tentuan, atau takut dari kenyataan yang dimiliki oleh seseorang pada saat menghadapi kenyataan atau kejadian dalam hidupnya. Lefrancois (dalam Anggraeni) menyatakan bahwa kecemasan merupakan reaksi emosi yang tidak menyenangkan, yang ditandai dengan ketakutan, adanya hambatan terhadap keinginan pribadi dan perasaan-perasaan yang tertekan yang muncul dalam kesadaran.

Dari hasil penelitian sebelumnya yang dilakukan oleh Riska (2016) menunjukan bahwa kemampuan koneksi matematis siswa masih belum maksimal, dan salah satu solusi yang dibuat untuk mengatasinya ialah dengan menggunakan model pembelajaran Mind Mapping kemudian pada penelitian yang dilakukan Nurmila (2016) menemukan bahwa dalam proses pembelajaran terdapat kebanyakan siswa merasa takut ketika ditunjuk mengerjakan soal oleh guru, gelisah ketika guru mata pelajaran matematika akan masuk ke kelas untuk mengajar, cenderung jantungnya berdebar kencang ketika ditunjuk mengerjakan soal, beberapa siswa yang emosi atau marah ketika temannya tidak memperlihatkan jawaban tugas matematika yang diberikan oleh gurunya.

Berdasarkan hal-hal di atas bahwa terdapat masalah terhadap kemampuan koneksi matematis dan tingginya kecemasan matematika siswa. Salah satu cara untuk mengatasi masalah-masalah di atas adalah dengan cara melakukan inovasi dalam pembelajaran matematika dengan menggunakan model atau metode pembelajaran yang dapat memperbaiki kemampuan koneksi matematis siswa dan mengurangi tingkat kecemasan matematika siswa yaitu Model pembelajaran Mind Mapping yang menekankan pada proses belajar aktif dan kreatif.

Model pembelajaran yang cocok untuk menimbulkan ide-ide kreatif sekaligus membuat pelajaran matematika menyenangkan adalah pembelajaran dengan model Mind Mapping. Menurut Tony Buzan mengungkapkan bahwa Mind Mapping adalah cara termudah untuk menempatkan informasi ke dalam otak dan mengambil informasi keluar otak, Mind Mapping adalah cara mencatat yang kreatif, efektif, dan secara harfiah akan memetakan pikiran-pikiran. Mind Mapping merupakan teknik meringkas bahan yang perlu dipelajari dalam bentuk peta, gambar, grafik, dan menggunakan warna agar lebih mudah memahaminya. Dengan model pembelajaran Mind Mapping yang banyak menggunakan gambar dan ilustrasi akan mengaktifkan otak kanan, dan menyeimbangkan otak kirinya. Sehingga pembelajaran matematika dirasa menyenangkan dan kecemasan siswa terhadap pembelajaran matematika pun lebih rendah. Oleh sebab itu, pembelajaran dengan model 
Mind Mapping mempunyai peluang terhadap kemampuan koneksi matematis dan kecemasan siswa dalam pembelajaran matematika lebih rendah.

Berdasarkan latar belakang yang telah di uraian di atas, maka peneliti tertarik untuk melakukan studi yang berfokus pada penerapan model pembelajaran yang diduga dapat memperbaiki kemampuan koneksi matematis dan mengurangi kecemasan matematika siswa, peneliti tertarik untuk melakukan penelitian yang berjudul "Penerapan Model Pembelajaran Mind Mapping Terhadap Kemampuan Koneksi dan Kecemasan Matematika Siswa SMP”.

Adapun tujuan dalam penelitian ini adalah untuk mengetahui kemampuan koneksi matematis siswa yang pembelajarannya menggunakan model Mind Mapping lebih baik daripada siswa yang menggunakan pembelajaran langsung dan ntuk mengetahui kecemasan matematik siswa yang pembelajarannya menggunakan model Mind Mapping lebih rendah daripada siswa yang menggunakan pembelajaran langsung.

Koneksi matematis berasal dari bahasa inggris yaitu "mathematical connection" yang kemudian dipopulerkan oleh NCTM. Koneksi dapat diartikan sebagai keterkaitan, sehingga koneksi matematis dapat diartikan sebagai keterkaitan suatu topik dengan topik lainnya namun masih dalam konteks matematika (koneksi internal), keterkaitan matematika dengan bidang ilmu lain, dan keterkaitan matematika dengan kehidupan nyata atau kehidupan sehari-hari (koneksi eksternal).

Menurut NCTM (Sari, 2014:8), koneksi matematik dibagi menjadi tiga klasifikasi, yaitu: (1) Koneksi antar topik matematika; (2) Koneksi dengan disiplin ilmu lain; dan (3) Koneksi dengan masalah-masalah dalam kehidupan sehari-hari. Bruner menyatakan dalam matematika setiap konsep berkaitan dengan konsep yang lain. Begitu pula dengan yang lainnya, misalnya dalil dan dalil, antara teori dan teori, antara topik dengan topik, ataupun antara cabang matematika dengan cabang matematika lain. Oleh karena itu agar siswa lebih berhasil dalam belajar matematika, maka harus banyak diberikan kesempatan untuk melihat keterkaitan-keterkaitan itu. Menurut Alistina (dalam Rendya, dkk (2012: 83) kemampuan koneksi penting dimiliki oleh siswa agar mereka mampu menghubungkan antara materi yang satu dengan materi yang lainnya.

Menurut Sarastika (2014) Kecemasan dapat diartikan sebagai ketegangan, rasa tidak aman dan kekhawatiran yang timbul karena dirasakan terjadi sesuatu yang tidak menyenangkan. Kecemasan masing-masing siswa berbeda, sesuai dengan kesukaan dan kecenderungan siswa terahadap mata pelajaran tertentu. Taylor (1953) dalam Tailor Manifest Anxiety Scale (TMAS) mengemukakan bahwa kecemasan merupakan suatu 
perasaan subyektif mengenai ketegangan mental yang menggelisahkan sebagai reaksi umum dari ketidakmampuan mengatasi suatu masalah atau tidak adanya rasa aman. Siswa yang mengalami kecemasan terhadap matematika merasa bahwa dirinya tidak mampu dan tidak bisa mempelajari materi matematika serta mengerjakan soal-soal matematika. Kecemasan merupakan unsur kejiwaan yang menggambarkan suatu keadaan perasaan, keadaan emosional, gelisah, ketidak tentuan, atau takut dari kenyataan yang dimiliki oleh seseorang pada saat menghadapi kenyataan atau kejadian dalam hidupnya.

Ashcraft (2002: 1) mendefinisikan kecemasan matematika sebagai perasaan ketegangan, cemas atau ketakutan yang mengganggu kinerja matematika. Siswa yang mengalami kecemasan matematika cenderung menghindari situasi dimana mereka harus mempelajari dan mengerjakan matematika. Sedangkan Richardson dan Suinn (1972) meyatakan bahwa kecemasan matematika melibatkan perasaan tegang dan cemas yang mempengaruhi dengan berbagai cara ketika menyelesaikan soal matematika dalam kehidupan nyata dan akademik.

Penelitian Jean Benner (2010) menyimpulkan bahwa kecemasan matematika bukanlah reaksi terhadap matematika itu sendiri, melainkan sebuah hasil dari kelas matematika. Ini berarti seorang guru harus bisa mencegah kecemasan matematika siswa di kelas. Pernyataan ini menjelaskan bahwa guru bertanggung jawab mengkondisikan kelas matematika sebagaimana yang diharapkan. Yaitu situasi yang dapat mencegah berkembangnya kecemasan matematika pada diri siswa.

Mind Mapping atau Peta Pikiran adalah cara mempelajari konsep yang ditemukan oleh Tony Buzan pada awal tahun 1970, seorang ahli dan penulis di bidang psikologi dari Inggris. Konsep ini didasarkan pada cara kerja otak kita menyimpan informasi. Mind Mapping dapat diartikan sebagai proses dari memetakan pemikiran untuk menghubungkan konsep-konsep tertentu dari cabang-cabang sel saraf yang membentuk korelasi konsep menuju pada suatu pemahaman dan hasilnya dituangkan langsung di atas selembar kertas dengan animasi yang disukai dan gampang dimengerti oleh pembuatnya. Sehingga hasil dari tulisan tersebut adalah merupakan gambaran langsung dari cara kerja koneksi-koneksi yang ada di dalam otak.

Kerja Mind Mapping atau peta pikiran adalah menuliskan tema utama sebagai titik sentral atau tengah dan memikirkan cabang-cabang atau tema-tema turunan yang keluar dari titik tengah tersebut dan mencari hubungan antara tema turunan. Itu berarti setiap kali kita mempelajari suatu hal maka fokus kita diarahkan pada apakah tema utamanya, poinpoin penting dari tema yang utama yang sedang kita pelajari, pengembangan dari setiap 
poin penting tersebut dan mencari hubungan antara setiap poin. Model Mind Mapping berguna untuk menampilkan pengetahuan secara lengkap sehingga memudahkan memori untuk melihat lagi pengetahuan yang dimiliki.

Anggraeni (2014) Mind mapping adalah cara mencatat yang kreatif, efektif, dan secara harfiah akan memetakan pikiran. Dengan menggunakan mind mapping, daftar informasi yang panjang dan menjemukan bisa diubah bentuknya menjadi diagram berwarna-warni, mudah diingat dan sangat beraturan serta sejalan dengan cara kerja alami otak. Mind mapping diperlukan karena banyak anak mengalami kesulitan ketika berusaha mengingat kembali apa yang telah didapatkan, dipelajari, direkam, dicatat atau yang dahulu pernah diingat. Hal ini terjadi dikarenakan catatan ataupun ingatannya belum teratur.

\section{METODE PENELITIAN}

Metode penelitian yang digunakan dalam penelitian ini menggunakan Metode True Experimental Design karena pada desain ini peneliti dapat mengontrol semua variabel luar yang mempengaruhi jalannya eksperimen.ciri utama dari metode ini adalah adanya kelompok kontrol dan sampel dipilih secara random.

Desain penelitian yang digunakan dalam penelitian ini adalah pretest-postest control group design atau desain dengan menggunakan dua kelompok. Kedua kelompok di pilih secara random. Kelompok pertama sebagai kelompok eksperimen yang memperoleh pembelajaran dengan menggunakan model Mind Mapping atau mendapat perlakuan dan kelompok kedua sebagai kelompok kontrol yang memperoleh pembelajaran langsung yang kemudian masing-masing kelompok mendapatkan tes awal dan tes akhir. Dalam penelitian ini yang merupakan variabel terikatnya adalah kemampuan koneksi dan kecemasan matematik siswa. Dan variabel bebasnya adalah model pembelajaran Mind Mapping.

Populasi adalah semua objek yang akan dihadapi oleh peneliti, baik berupa benda, manusia, maupun peristiwa. Populasi dalam penelitian ini adalah seluruh siswa kelas VII SMPIT Adzkia Sukabumi tahun ajaran 2018/2019. Alasan dipilihnya siswa kelas VII bahwa mereka sudah dapat beradaptasi dengan model pembelajaran baru dan tidak mengganggu program sekolah untuk menghadapi ujian akhir seperti kelas IX.

Pemilihan sampel dilakukan dengan teknik Simple Random Sampling, yaitu memilih secara acak dari kelompok-kelompok yang ada dalam populasi. Sugiyono (2014) dikatakan simple (sederhana) karena pengambilan anggota sampel dari populasi dilakukan secara acak tanpa memperhatikan strata dari populsi itu. Keseluruhan populasi terdiri dari 
enam kelas yaitu Kelas VII-A, VII-B, VII-C, VII-D, VII-E dan VII-F. Dari ke enam kelas tersebut dipilih dua kelas secara acak untuk menjadi sampel penelitian. Untuk memilih sampel tersebut digunakan cara acak kelas. Dilakukan dengan cara acak agar setiap anggota populasi memiliki peluang yang sama untuk terpilih menjadi sampel, dan agar pemilihan sampel ini terhindar dari hal-hal yang bersifat subjektif. Pemilihan dilakukan dengan cara mengundi, dan tenyata pemilihan jatuh pada kelas VII-E dan VII-F. Dari kedua kelas ini di pilih lagi secara acak untuk menentukan kelas eksperimen dan kelas kontrol. Dengan cara diundi terpilih kelas VII-E dengan jumlah siswa 20 orang sebagai kelas kontrol yang mendapatkan model pembelajaran langsung dan kelas VII-F dengan jumlah siswa 25 orang sebagai kelas eksperimen yang mendapatkan perlakuan dengan model Mind Mapping.

Pada penelitian ini tes yang digunakan yaitu tes kemampuan koneksi matematis untuk mengetahui sejauh mana kemampuan koneksi matematis siswa. Tes dalam penelitian ini berbentuk soal uraian atau biasa disebut tes subjektif dan Angket Kecemasan Matematika. Angket skala kecemasan ini berisikan berbagai pernyataan-pernyataan siswa mengenai pembelajaran matematika, soal-soal yang diberikan dan pembelajaran yang dilakukan dengan model Mind Mapping. Skala kecemasan yang digunakan adalah skala kecemasan tertutup, artinya jawaban sudah disediakan dan siswa hanya memilih salah satu alternatif jawaban yang sudah disediakan yang paling sesuai dengan pendapatnya. Angket skala kecemasan ini diberikan kepada kelas eksperimen setelah seluruh pembelajaran dilaksanakan. Setiap responden menjawab suatu pernyataan dengan jawaban Sangat Sering (SS), Sering (S), Jarang (J), dan tidak pernah (TP). Masing-masing jawaban dikaitkan dengan skor atau nilai. Bagi suatu pernyataan skor yang diberikan untuk $\mathrm{SS}=1, \mathrm{~S}=2, \mathrm{~J}=$ 3 , dan $\mathrm{TP}=4$.

\section{HASIL DAN PEMBAHASAN}

Pada bab ini akan dipaparkan mengenai hasil penelitian dan pembahasan dari seluruh kegiatan penelitian yang telah dilaksanakan. Data yang diperoleh dalam penelitian ini adalah data nilai tes kemampuan koneksi matematis siswa dan data hasil angket kecemasan matematik siswa. Adapun alat untuk mengolah data dilakukan dengan menggunakan Microsoft Excel. 


\section{Analisis Data Tes Akhir (Postes)}

Setelah memberi perlakuan dengan model Mind Mapping pada kelas eksperimen dan model pembelajaran langsung pada kelas kontrol, untuk mengetahui kemampuan koneksi matematik siswa kelas eksperimen dan kelas kontrol, maka pada masing-masing kelas diberikan soal postes. Seteah mendapatkan data maka hasilnya di hitung menggunakan Microsoft Excel.

Tabel 5. Normalitas Postes Eksperimen dan Kontrol

\begin{tabular}{ccc}
\hline Normalitas Postes & Rerata & 67,60 \\
Eksperimen & Varians & 702,33 \\
& simpangan baku & 26,50 \\
& Lmaks=maks $|\mathrm{F}(\mathrm{Zi})-\mathrm{S}(\mathrm{Zi})|$ & 0,1608 \\
& L tabel & 0,1730 \\
Normalitas Postes & Rerata & 53,50 \\
EKontrol & Varians & 587,11 \\
& simpangan baku & 24,23 \\
& Lmaks=maks $|\mathrm{F}(\mathrm{Zi})-\mathrm{S}(\mathrm{Zi})|$ & 0,1162 \\
\hline
\end{tabular}

Diperoleh data bahwa skor rata-rata nilai awal untuk kelas eksperimen adalah 67,60 dan skor rata-rata nilai awal untuk kelas kontrol adalah 53,50 dengan varians untuk kelas eksperimen adalah 702,33 dan varians untuk kelas kontrol adalah 587,11 dan nilai L maks pada kelas eksperimen adalah 0,1608 dan pada kelas kontrol adalah 0,1162. Sehingga Keputusan Uji yaitu: dikarenakan pada kelas Eksperimen Lmaks $=0,1608<0,1730$ berada di daerah terima $\mathrm{H}_{0}$ maka $\mathrm{H}_{0}$ diterima. Sehingga dari tabel di atas dapat disimpulkan bahwa data berdistribusi normal.

Pengujian homogenitas data dimaksudkan untuk menguji apakah data sampel yang berasal dari populasi yang dikumpulkan berbentuk homogen atau tidak. Berikut hasil pengujian data dengan menggunakan Uji Homogenitas dengan bantuan Microsoft Excel.

Tabel 6. Uji Homogenitas Pretes

\begin{tabular}{cccc}
\hline Kemampuan & $\mathbf{F}_{\text {hitung }}$ & $\mathbf{F}_{\text {tabel }}$ & Keterangan \\
Koneksi Matematik & 0,84 & 2,01 & Homogen \\
\hline
\end{tabular}

Dari tabel diatas hasil perhitungan dengan taraf signifikan 5\%, dapat disimpulkan bahwa data homogen karena semua $\mathrm{F}_{\text {hitung }}<\mathrm{F}_{\text {tabel }}$ atau dengan kata lain, $\mathrm{H}_{0}$ diterima artinya kedua kelas homogen. Karena kedua sampel berdistribusi normal dan homogen, maka dilakukan uji perbedaan dua rata-rata.

Karena kedua sampel (kelas eksperimen dan kelas kontrol) berasal dari populasi yang berdistribusi normal dan memiliki varians yang homogen maka dilanjutkan dengan 
Uji-t yaitu dengan menggunakan Independent Sample t-Test dengan asumsi kedua varians homogen untuk menguji kesamaan dua rata-rata, taraf signifikansinya 0,01 .

Berdasarkan pengujian hipotesis untuk kemampuan koneksi matematik dengan menggunakan uji $\mathrm{t}$, diperoleh hasil $\mathrm{t}_{\text {hitung }}=-6,000$ sedangkan nilai $\mathrm{t}_{\text {tabel }}=-2,326$. Sehingga $\mathrm{H}_{0}$ ditolak atau $\mathrm{H}_{1}$ diterima karena $\mathrm{t}_{\text {hitung }}<\mathrm{t}_{\text {tabel. }}$. Dengan demikian, hipotesis yang diajukan bahwa kemampuan koneksi matematis kelas eksperimen lebih baik dibandingkan kelas kontrol.

Hasil kecemasan matematik diperoleh dengan memberikan angket kecemasan matematik kepada siswa kelas eksperimen yang mendapatkan pembelajaran matematika dengan menggunakan model Mind Mapping. Di dalam angket tersebut, terdapat 28 pernyataan yang mana dibagi ke dalam 4 bagian.. Bagian pertama adalah indikator kecemasan reaksi kognitif siswa terhadap pelajaran matematika, bagian kedua adalah indikator kecemasan reaksi afektif siswa terhadap pembelajaran matematika, bagian ketiga adalah indikator kecemasan reaksi psikomotorik siswa terhadap pembelajaran matematika, dan bagian keempat adalah indikator kecemasan reaksi somatik siswa terhadap pembelajaran matematika. Adapun data hasil angket pada Tabel 7.

Tabel 7. Hasil Angket Kecemasan Matematika

\begin{tabular}{cccc}
\hline Angket & Rata-rata & Presentase & Keterangan \\
\hline $\begin{array}{c}\text { Kecemasan } \\
\text { Matematika }\end{array}$ & 76,54 & $77 \%$ & $\begin{array}{c}\text { Kadang-kadang } \\
\text { cemas }\end{array}$ \\
\hline
\end{tabular}

Dari Tabel 7 di dapat hasil angket kecemasan matematika siswa dengan nilai ratarata adalah 76,54 dengan presentase $77 \%$ yang menunjukkan bahwa kecemasan matematika siswa adalah kadang-kadang cemas. Data observasi pada penelitian ini diperoleh dengan menggunakan lembar observasi guru dan siswa selama penelitian sebanyak 5 kali pertemuan. Berikut penjelasan mengenai hasil lembar observasi guru dan siswa dalam kegiatan pembelajaran dengan menggunakan model pembelajaran Mind Mapping. Lembar observasi guru dilakukan sebanyak 5 kali sesuai dengan banyaknya pertemuan yang dilakukan peneliti selama melaksanakan penelitian. Berdasarkan pengamatan observer yang tertuang dalam lembar observasi, peneliti telah mampu melaksanakan tugas dan peranannya dengan baik. Walaupun pada pertemuan pertama masih ada kekurangan, namun pada pertemuan selanjutnya peneliti bisa memperbaiki kekurangan yang terjadi pada pembelajaran sebelumnya, sehingga bila dilihat pada hasil lembar observasi pada setiap pertemuan selalu ada peningkatan. Dalam hal ini aspek yang diamati pada lembar observasi guru adalah langkah-langkah kegiatan dalam pembelajaran Mind Mapping. 
Berikut adalah data hasil observasi keterlaksanaan pembelajaran dengan menggunakan model pembelajaran Mind Mapping pada pertemuan ke-1 sampai dengan pertemuan ke-5 dengan perolehan skor maksimal pada lembar observasi guru adalah $100 \%$.

Tabel 8. Data Hasil Lembar Observasi Guru

\begin{tabular}{|c|c|c|c|c|c|c|}
\hline No & Hari/Tanggal & Waktu & $\begin{array}{l}\text { Pertemuan } \\
\text { Ke }\end{array}$ & $\begin{array}{c}\text { Rata-rata } \\
\text { Skor }\end{array}$ & $\begin{array}{c}\text { Prosentase } \\
\text { Skor }\end{array}$ & Ket. \\
\hline 1 & $\begin{array}{l}\text { Senin, } \\
20 \text { Mei } 2019\end{array}$ & $08.00-09.20$ & 1 & 1,45 & $36,2 \%$ & kurang \\
\hline 2 & $\begin{array}{l}\text { Selasa, } \\
21 \text { Mei } 2019\end{array}$ & $08.00-10.00$ & 2 & 1,70 & $42,5 \%$ & cukup \\
\hline 3 & $\begin{array}{l}\text { Selasa, } \\
21 \text { Mei } 2019\end{array}$ & $13.00-14.20$ & 3 & 2,45 & $61,2 \%$ & cukup \\
\hline 4 & $\begin{array}{l}\text { Rabu, } \\
22 \text { Mei } 2019\end{array}$ & $08.00-09.20$ & 4 & 3,00 & $75 \%$ & sedang \\
\hline 5 & $\begin{array}{l}\text { Rabu, } \\
22 \text { Mei } 2019\end{array}$ & $13.00-14.20$ & 5 & 3,12 & $78 \%$ & Sedang \\
\hline
\end{tabular}

Berdasarkan Tabel 8 terlihat bahwa rata-rata keterlaksanaan pembelajaran matematika dengan menggunakan model Mind Mapping pada setiap pertemuannya selalu ada peningkatan, itu artinya peneliti bisa memperbaiki kekurangan yang terjadi pada pertemuan sebelumnya. Jika melihat presentase skor yang diperoleh pada lembar observasi guru diatas dapat disimpulkan bahwa pelaksanaan pembelajaran sudah sesuai dengan karakteristik model pembelajaran Mind Mapping. Dengan kata lain hasil akhir lembar observasi guru pada pertemuan ke-5 dengan presentase skor $78 \%$ jika dilihat pada klasifikasi interpretasi adalah baik.

Sama halnya seperti lembar observasi pada guru, lembar observasi siswa juga dilaksanakan dan diamati oleh seorang observer selama melaksanakan penelitian atau sebanyak 5 kali pertemuan. Berikut adalah data hasil observasi keterlaksanaan pembelajaran dengan menggunakan model pembelajaran Mind Mapping pada pertemuan ke-1 sampai dengan pertemuan ke-5 dengan skor maksimal pada lembar observasi siswa adalah $100 \%$ untuk lembar observasi kemampuan koneksi matematik.

Tabel 9. Data Hasil Lembar Observasi Siswa

\begin{tabular}{clcccc}
\hline No & \multicolumn{1}{c}{ Hari/Tanggal } & Waktu & $\begin{array}{c}\text { Pertemuan } \\
\text { Ke }\end{array}$ & $\begin{array}{c}\text { Jumlah } \\
\text { Skor }\end{array}$ & $\begin{array}{c}\text { Prosentase } \\
\text { Skor }\end{array}$ \\
\hline 1 & $\begin{array}{l}\text { Senin, } \\
\text { 20 Mei 2019 }\end{array}$ & $08.00-09.20$ & 1 & 6 & $40 \%$ \\
2 & $\begin{array}{l}\text { Selasa, } \\
\text { 21 Mei 2019 }\end{array}$ & $08.00-10.00$ & 2 & 7 & $47 \%$ \\
3 & $\begin{array}{l}\text { Selasa, } \\
\text { 21 Mei 2019 }\end{array}$ & $13.00-14.20$ & 3 & 9 & $60 \%$ \\
4 & $\begin{array}{l}\text { Rabu, } \\
\text { 22 Mei 2019 }\end{array}$ & $08.00-09.20$ & 4 & 11 & $73 \%$ \\
\hline
\end{tabular}




\begin{tabular}{cccccc}
\hline No & Hari/Tanggal & Waktu & $\begin{array}{c}\text { Pertemuan } \\
\text { Ke }\end{array}$ & $\begin{array}{c}\text { Jumlah } \\
\text { Skor }\end{array}$ & $\begin{array}{c}\text { Prosentase } \\
\text { Skor }\end{array}$ \\
\hline 5 & $\begin{array}{l}\text { Rabu, } \\
\text { 22 Mei 2019 }\end{array}$ & $13.00-14.20$ & 5 & 12 & $80 \%$ \\
\hline
\end{tabular}

Berdasarkan Tabel 9 terlihat bahwa rata-rata keterlaksanaan pembelajaran matematika dengan menggun akan model Mind Mapping pada setiap pertemuannya selalu ada peningkatan, itu artinya siswa bisa memperbaiki kekurangan yang terjadi pada pertemuan sebelumnya. Jika melihat presentase skor yang diperoleh pada lembar observasi siswa diatas dapat disimpulkan bahwa pelaksanaan pembelajaran sudah sesuai dengan karakteristik model pembelajaran Mind Mapping. Dengan kata lain hasil akhir lembar observasi siswa pada pertemuan ke-5 dengan presentase $80 \%$ jika dilihat pada klasifikasi interpretasi adalah baik.

Dari data hasil pretes yang telah diuji, menunjukkan bahwa perbedaan rata-rata antara kelas kontrol dan kelas eksperimen tidak berbeda secara signifikan. Artinya, kemampuan awal siswa baik kelas kontrol dengan kelas eksperimen tidak terlalu berbeda. Setelah digunakan pembelajaran matematika dengan model Mind Mapping pada kelas eksperimen dan model pembelajaran langsung pada kelas kontrol, kedua kelas tersebut diberikan postes kemampuan koneksi matematis. Hasil perhitungan setelah dilakukan postes kemampuan koneksi matematis siswa, ternyata rata-rata kelas eksperimen lebih besar daripada kelas kontrol. Secara kasar terlihat bahwa peningkatan kemampuan koneksi matematis siswa kelas eksperimen lebih baik dari kelas kontrol.

Maka dapat disimpulkan bahwa kemampuan koneksi matematis siswa yang pembelajarannya menggunakan model Mind Mapping lebih baik daripada siswa yang menggunakan pembelajaran langsung. Adapun kendala dalam penelitian ini yaitu beberapa siswa terlihat tidak bersemangat karena mungkin pelajaran matematika ditempatkan di jam pelajaran terakhir. Sehingga tidak mudah untuk mengkondusifkan kelas. Kendala lain yang ditemukan peneliti adalah masih adanya siswa yang kurang terlibat aktif dalam diskusi kelompok, akan tetapi bersemangat ketika mengerjakan tugas kelompok dalam pembuatan Mind Mapping.

Untuk mengetahui rendahnya kecemasan matematika belajar siswa setelah menggunakan model pembelajaran Mind Mapping perlu diketahui terlebih dahulu bagaimana kecemasan matematika siswa sebelum kegiatan menggunakan model pembelajaran Mind Mapping. Dari hasil penelitian, bahwa tidak terdapat perbedaan yang 
signifikan antara kecemasan matematika siswa baik kelas kontrol dengan pembelajaran langsung dan siswa kelas eksperimen dengan model pembelajaran Mind Mapping.

Peneliti mengalasis hasil angket menggunakan Microsoft Excel, dari hasil yang di dapatkan relatif memperlihatkan rendahnya kecemasan matematika, terlihat dari rata-rata yang didapat termasuk pada kategori kadang-kadang cemas, ini bisa dikatakan bahwa kecemasan matematika siswa di kelas eksperimen lebih rendah daripada kelas kontrol yang mendapat model pembelajaran langsung. Keadaan ini memberikan gambaran bahwa model pembelajaran Mind Mapping sangat berpengaruh terhadap kecemasan matematika siswa.

Berdasarkan tabel observasi guru terlihat bahwa rata-rata keterlaksanaan pembelajaran matematika dengan menggunakan model Mind Mapping pada setiap pertemuannya selalu ada peningkatan, itu artinya peneliti bisa memperbaiki kekurangan yang terjadi pada pertemuan sebelumnya. Jika melihat prosentase skor yang diperoleh pada lembar observasi guru diatas dapat disimpulkan bahwa pelaksanaan pembelajaran sudah sesuai dengan karakteristik model pembelajaran Mind Mapping. Dengan kata lain hasil akhir lembar observasi guru pada pertemuan ke-5 dengan prosentase skor $78 \%$ jika dilihat pada interval yang terdapat pada lembar observasi guru tersebut adalah baik.

Berdasarkan tabel diatas terlihat bahwa rata-rata keterlaksanaan pembelajaran matematika dengan menggunakan model Mind Mapping pada setiap pertemuannya selalu ada peningkatan, itu artinya siswa bisa memperbaiki kekurangan yang terjadi pada pertemuan sebelumnya. Jika melihat prosentase skor yang diperoleh pada lembar observasi siswa diatas dapat disimpulkan bahwa pelaksanaan pembelajaran sudah sesuai dengan karakteristik model pembelajaran Mind Mapping. Dengan kata lain hasil akhir lembar observasi siswa pada pertemuan ke-5 dengan prosentase skor $80 \%$. jika dilihat pada interval yang terdapat pada lembar observasi siswa tersebut adalah kecemasan matematik siswa berkurang.

\section{REFERENSI}

Amiruddin. (2016). Peningkatan Kemampuan Pemahaman Konsep dan Berpikir Kritis Melalui Model Pembelajaran Contextual Teaching And Learning. Sukabumi: Tidak diterbitkan.

Anggraeni, T. (2009). "Pengaruh Antara Kecemasan Dalam Menghadapi Mata Pelajaran Matematika Dengan Prestasi Akademik Matematika Pada Remaja”. Skripsi; tidak diterbitkan.

Ashcraft, M.H. (2002). "Math Anxiety: Personal, Educational, and Cognitive Consequences". Directions in Psychological Science. 11.

Benner, J. (2010). Anxiety in The Math Classroom. Bemidji State Universty. Tesis. Tidak Diterbitkan. 
Buzan, T. (2008). Buku Pintar Mind Map. Jakarta: Gramedia

Linto, R. L. (2012). "Kemampuan Koneksi Matematis Dan Metode Pembelajaran Quantum Teaching Dengan Peta Pikiran". Jurnal Pendidikan Matematika, Part 2 : Hal. 83-87

Mariana, S. (2011). Penerapan Pendekatan Kontekstual dengan Pemberian Tugas Mind Map Setelah Pembelajaran Terhadap Peningkatan Kemampuan Koneksi Matematis Siswa SMP. Skripsi Jurusan Pendidikan Matematika FPMIPA UPI: Tidak DiterbitkaN.

NCTM, (2000). Principle and Standarts of School Mathematics. Reston: NCTM

Nelly Y. (2013), Pengaruh Pendekatan Difverentiated Instruction Terhadap Kecemasan Matematika (Math Anxiety), Peningkatan Kemampuan Pemahaman dan Penelaran Matematis Siswa SMK. Tesis PPs UPI. Bandung: tidak diterbutkan

Novianti, S. D. (2016). Pengaruh Penggunaan Metode Personalized System Of Intruction (PSI) Terhadap Kemampuan Representasi Dan Kemandirian Belajar Matematika Siswa SMP. Bandung: Tidak diterbitkan.

Nurmila. (2016). "Hubungan Antara Kecemasan Matematika Dan Kesulitan Belajar Dengan Perilaku Belajar Siswa Di Smpn 3 Tanete Riaja Kabupaten Barru”. Skripsi Fakultas Tarbiyah Dan Keguruan Uin Alauddin Makassar: tidak diterbitkan.

Permendiknas. (2006). Standar Isi Satuan. Jakarta: Permendiknas.

Plainsance, D.V. (2010). " A Teacher's Quick Guide to Understanding Mathematics Anxiety". Louisiana Association of Teachers (LATM) Journal, 6,(1).

Richarson, F.C. dan Suinn, R.M. (1972)"The Mathematics Anxiety Rating Scale Psychometric Data”. Journal of Counseling Psychology, 19 (6), 551-554).

Riyanto, A. (2016). "Pengaruh Strategi Pembelajaran Think-Talk-Write (Ttw) Terhadap Kemampuan Komunikasi Matematis Siswa SMA”. Skripsi Unpas Bandung. Tidak diterbitkan.

Ruspiani. (2000). Kemampuan Siswa dalam Melakukan Koneksi Matematika. Tesis pada PPS UPI: Tidak diterbitkan.

Sarastika, P. Manajemen Pikiran untuk Mengatasi Stres, Depresi, Kemarahan dan kecemasan (Yogyakarta: Araska, 2014) h:160

Sari, Riska N. (2014). Penggunaan Model Mind Mapping Pada Pembelajaran Matematika untuk Meningkatkan Kemampuan Koneksi Matematik Siswa SMA. Skripsi FKIP UNPAS. Bandung: Tidak diterbitkan.

Sugiyono, (2014). Metode Penelitian Pendidikan, Bandung: Alfabeta.

Taylor, J. A. (1953). "A Personality Scale of Manifest Anxiety". Jounal of Abnormal and Social Psychology, 48, 285-190.

Trianto. (2010). Mendesain Model Pembelajaran Inovatif Progresif. Jakarta: Kencana Prenada Media 